\title{
A $100 \%$ Tree Inventory Using i-Tree Eco Protocol: A Case Study at Auburn University, Alabama, U.S.
}

\author{
Nicholas A. Martin, Arthur H. Chappelka, Gary J. Keever, and Edward F. Loewenstein
}

\begin{abstract}
The Auburn University campus in Auburn, Alabama, U.S., was used as the site for a case study on the applicability of i-Tree Eco using a 100\% tree inventory. The 2009-2010 inventory of the managed areas of campus encompassed 238 ha. Information collected from each tree included diameter at breast height (DBH), tree height, crown width, percent dieback, and a tree condition rating. The complete inventory included 7,345 trees with Lagerstroemia spp. (crapemyrtle), Quercus phellos (willow oak), and Pinus taeda (loblolly pine) being the most numerous species on campus. Average DBH and total height of all trees were $16.4 \mathrm{~cm}$ and $8.5 \mathrm{~m}$, respectively, with an estimated canopy cover of approximately $16 \%$. Two tree condition ratings were recorded for each tree and results indicated that percent dieback alone is not a sufficient measure to evaluate tree condition. In this case study, i-Tree Eco procedures were found to be an effective and efficient tool, and provided valuable information regarding Auburn University's urban forest structure and function.

Key Words. i-Tree Eco; Tree Inventory; UFORE Model; Urban Forest Sampling, Urban Forestry.
\end{abstract}

The urban forest, defined as "ecosystems characterized by the presence of trees and other vegetation in association with people and their developments" (Nowak et al. 2001), is an ever changing landscape due to human activities and the environment. Research has been conducted to quantify the impacts of trees in urban settings (Dwyer et al. 1991; McPherson et al. 1997; Nowak and Crane 1998; Nowak et al. 2008a; Pandit and Laband 2010), but more research is needed due to the importance of trees in mitigating many impacts of urban development. Trees alleviate those impacts by moderating climate; conserving energy, carbon dioxide, and water; improving air quality; and by enhancing the attractiveness of a city (Dwyer et al. 1992).

To accurately assess the urban forest and its environmental impact, one has to know its composition and structure. Tree inventories are conducted and analyzed to provide this information. Traditionally, data regarding urban forest structure were gathered on street and park trees (Hauer et al. 1994; Welch 1994), but due to increasing concerns, inventories were expanded to encompass vegetation in other parts of the urban forest, including residential, industrial, and abandoned lands (McPherson et al. 1997). Obviously, conducting a $100 \%$ inventory is the most accurate, but unless it is being conducted on relatively small areas, it is not as cost effective as random sampling (Nowak et al. 2008a; Nowak et al. 2008b).

Inventories provide information on forest structure (e.g., tree species, number, size and/or age, location) (Nowak and Crane 1998; Nowak et al. 2008a; Nowak et al. 2008b) and are the basis for deriving measurements of ecosystem services, including carbon storage and sequestration, and energy savings (Nowak et al. 2008a). Inventories can also determine compensatory values of trees, or the monetary value in the urban environment to the individual owner (Nowak et al. 2002). These evaluations also aid in determining real estate value (Dwyer et al. 1992) and assessing liabilities and risks (Matheny and Clark 2009).
Researchers from the United States Department of Agriculture (USDA) Forest Service developed a tool that can improve inventory efficiency and provide the environmental information necessary to understand urban forest structure and values (Nowak and Crane 1998). The Urban Forest Effects (UFORE) model was developed to help resource managers and researchers quantify the structure of the urban forest and the functions of urban ecosystems (Nowak and Crane 1998). The model is a science-based, peerreviewed computer model (i-Tree 2010b) that estimates structural aspects, such as species composition and diversity, tree density and overall health, and leaf area, as well as volatile organic compound emissions, the total amount of carbon stored and sequestered, and pollution removal and the associated percent improvement in air quality (Nowak and Crane 1998). Currently, projects and inventories utilizing the model are now referred to as i-Tree Eco projects and inventories; however, the actual computer model used at the time of this study was the UFORE model (i-Tree 2010a).

The overall purpose of this research project was to assess the applicability of using i-Tree Eco protocol to conduct a $100 \%$ inventory. A university campus is an ideal location for such an inventory. The data collected can be used for several purposes: identification of major tree species, evaluation of height and diameter distribution, and evaluation of tree health. In addition, the model can be used to determine various ecosystem services, including carbon storage and air pollution removal, which may be important in identifying the "human footprint" on campus. The Auburn University (Auburn, Alabama, U.S.) campus was an ideal location to conduct this evaluation. Specific objectives of the study were: 1) complete a $100 \%$ tree inventory of the managed areas on the Auburn University campus using a format that is UFORE compatible and follows i-Tree Eco protocol, and 2) evaluate dieback as an overall indicator of tree condition. 


\section{MATERIALS AND METHODS}

\section{Study Site}

The study site was the Auburn University campus $\left(32^{\circ} 36^{\prime} \mathrm{N}\right.$, $\left.85^{\circ} 30^{\prime} \mathrm{W}\right)$. The core campus encompasses approximately 306 ha. The inventory included the managed and landscaped portions of campus, which covered approximately 238 ha.

\section{Inventory}

The method of assessment for this project was a $100 \%$ tree inventory in an i-Tree Eco compatible form (i-Tree 2010c; i-Tree 2010d). The managed areas of campus were first divided into 99 sections and numbered using spring 2008 aerial photographs courtesy of the City of Auburn (Figure 1). The study area was divided into sections to provide a layout for inventory crews to follow and keep track of areas ("bookkeeping") that had and had not been inventoried. Section perimeters were determined by selecting borders such as streets and sidewalks where possible, and natural borders in all other cases so that sections were easily distinguishable. Sections were numbered starting with central campus and moving outward.

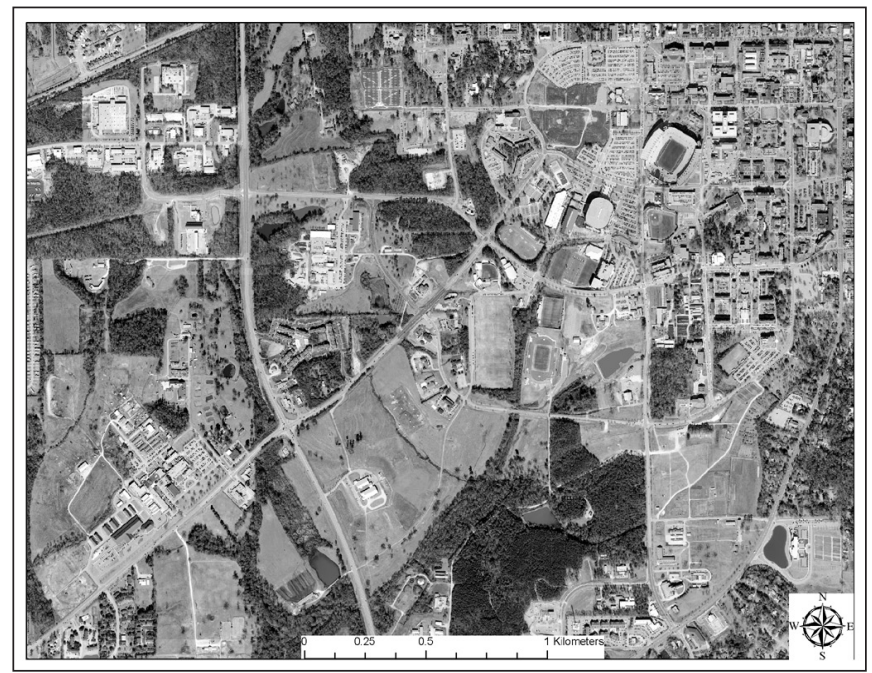

Figure 1. Aerial photograph of the Auburn University campus in spring 2008.

\section{Data Collection}

All data were collected following i-Tree Eco tree inventory protocol (i-Tree 2010c). Field data were collected by crews consisting of 1-3 members. A Global Positioning System (GPS) unit (either a Trimble GeoXM GeoExplorer ${ }^{\circledR} 2005$ or a Trimble GeoXT GeoExplorer ${ }^{\circledR} 2008$ series, with an external antenna on a tripod) was used to collect forest structure data in a data dictionary. The software used on the GPS units was TerraSync ${ }^{\mathrm{TM}}$ v.2.4.

The correct section was identified and the number entered into the collection unit. Total number of stems per tree was recorded and diameter at breast height $(\mathrm{DBH})(1.37 \mathrm{~m}$ above ground) was obtained using a logger's diameter tape. Minimum tree DBH to be included in the inventory was $2.54 \mathrm{~cm}$. For multi-stem trees, up to the six largest stems were recorded at breast height. For those trees that could not be measured at breast height, the measurement was taken at $0.3 \mathrm{~m}$ from the ground line. Crapemyrtle (Lagerstroemia spp.) was the only species measured at $0.3 \mathrm{~m}$ from the ground for all specimens, because the majority of the trees were not measurable at breast height due to their inherent form. Total tree and bole height were evaluated using a laser hypsometer (either a MDL LaserAce $^{\circledR}$ hypsometer or a Laser Technology, Inc. TruPulse ${ }^{\mathrm{TM}} 360 \mathrm{~B}$ rangefinder). Total tree height was determined by measuring from the ground line to the top (alive or dead) of the tree, and bole height was recorded as the height to the lowest branch of significance. Crown width was determined by taking two measurements from the crown edges at 90 degree angles and averaging them.

Data collected were downloaded from the GPS units to a desktop computer (daily) using the Trimble GPS Pathfinder ${ }^{\circledR}$ Office v.4.1 and 4.2 software. The ESRI ArcGIS ${ }^{\circledR} 9$ ArcMap $^{\mathrm{TM}}$ v.9.3 software was used for final data presentation. Once all data collection was completed, it was sent to the USDA Forest Service for analysis.

\section{Tree Condition Rating}

Dieback and percent missing crown were determined for each tree. Dieback of branches that appeared to have died from the terminal ends was evaluated by observing all sides of the tree and assigning an overall estimate of the percent dieback. Ranges of $<1,1-10,11-25,26-50,51-75,76-99$, and 100\% dieback were used to assign tree conditions of Excellent, Good, Fair, Poor, Critical, Dying, and Dead, respectively. The percent missing, or the amount of the crown that was missing, was determined the same way as percent dieback, by viewing all sides of a tree and estimating the overall percent missing in 5\% increments. Missing crowns could be due to impacts such as directional pruning or branches being lost due to damage (e.g., ice, wind).

In addition to the i-Tree Eco protocol, an overall condition rating was assigned as a comparison by assessing all aspects of a tree that were visible, including dieback and missing crown, trunk or limb damage, the presence of insects or disease, visible root damage, and the proximity to infrastructure. The condition rating used was a modification of other ratings (Webster 1978; CTLA 2000). The rating scale was: $6=$ Excellent condition, 5 = Good, $4=$ Fair, $3=$ Poor, $2=$ Very Poor, and $1=$ Dying/Dead. Excellent condition consisted of no missing crown, dieback, visible damage, or disease and pest presence. Good condition constituted $<10 \%$ dieback, missing crown, visible structural damage, and injury from diseases and pests; whereas a condition rating of Fair had 10\%-25\%, Poor had $25 \%-50 \%$, Very Poor had 50\%-75\%, and Dying/ Dead had $>75 \%$ of the tree being affected by one or more maladies. The most noticeable (ocular observation) damaging factor was used as the deciding reason when assigning the condition rating. To reduce subjectivity, each crew member would rate tree condition independently, and then all crew members would discuss and arrive at one tree condition rating.

To evaluate dieback as a tree condition indicator, the study authors compared the rating to the overall tree condition rating for every tree on campus. To analyze the data, dieback ranges were assigned a numerical value, where $<1 \%=6,1 \%-10 \%=5,11 \%-25 \%=4,26 \%-50 \%=3$, $51 \%-75 \%=2$, and $76 \%-99 \%$, and $100 \%=1$; and the tree condition ratings used the assigned numbers. For the analysis, trees rated as Excellent and Good by the dieback and overall condition ratings were combined into one group. 
A $\chi^{2}$ test was used to discern if there was no significant difference between dieback (i-Tree Eco) and overall tree condition rating (developed by the crew) for every tree on campus.

\section{RESULTS}

\section{Campus Inventory}

There were 7,345 trees inventoried on the Auburn University campus, which comprised 139 species (Table 1) that averaged $16.4 \mathrm{~cm}$ in DBH. Nine species accounted for almost $64 \%$ of the total population (Figure 2; Table 2). Crapemyrtle (Lagerstroemia spp.) and four oak (Quercus) species comprised more than $40 \%$ of the total population. Fifty-six percent of the total tree population on campus is $<7 \mathrm{~m}$ and $<1 \%$ are $30 \mathrm{~m}$ or more in height (Figure 3a). Sixtyfour percent of the population has a diameter $<21 \mathrm{~cm}$ (Figure $3 \mathrm{~b}$ ). It is important to note that the large number of crapemyrtles contributes to the skewed results for both height and diameter; without these trees, the height distribution peaks in the 5-6 $\mathrm{m}(1,482$ trees) range and peaks in the $8-12.9 \mathrm{~cm}(1,230$ trees) range for DBH. Total canopy cover was approximately $16 \%$ and the overall value was estimated at approximately USD \$10 million (Table 1).

\section{Tree Condition on the AU campus}

Tree condition was a minor component of the original inventory; however, evaluating the effectiveness of using dieback as an indicator of tree condition versus overall condition became an important issue in the evaluation of i-Tree Eco. The tree condition rating for the campus is shown in Figure 4a. Using the protocol developed by the study authors, it was determined that more than $60 \%$ of the total tree population was rated as Excellent or Good condition; however, using model-derived data (dieback) as an indicator of tree condition, $93 \%$ of the population was rated as being in Excellent or Good condition (Figure $4 \mathrm{~b}$ ). The overall condition rating also ranked approximately $3 \%$ of the trees being in Very Poor and Dying/Dead condition and the model rated about $1 \%$ of the trees in Critical and Dying/Dead condition. The comparison of dieback and the overall tree condition rating using a $\chi^{2}$ test resulted in a statistically significant difference $(P$ value $<0.0001)$ in the two rating systems (Table 3 ).

\section{DISCUSSION}

Following additional research on the part of the study authors, it was determined that this is likely the first published data on a $100 \%$ tree inventory having used i-Tree Eco protocols. Using these data allowed the authors to determine species composition, size distribution, and diversity. They also determined the relative value and tree condition. These data are very useful to the land manager in planning and maintaining a healthy, viable forest. The model has predominately been employed to assess the urban forests of larger cities (Nowak and Crane 1998; Nowak et al. 2002; Nowak et al. 2008a; Nowak et al. 2008b). The Auburn University $100 \%$ tree inventory case study is small in scale when compared to other i-Tree Eco study sites; however, it is comparable in certain aspects. To compare the complete tree data with data collected using the i-Tree Eco protocol (plots), the authors used results from Auburn, AL (Huyler et al. 2010) and Gainesville, Florida, U.S. (Escobedo et al. 2009a; Escobedo et al. 2009b).

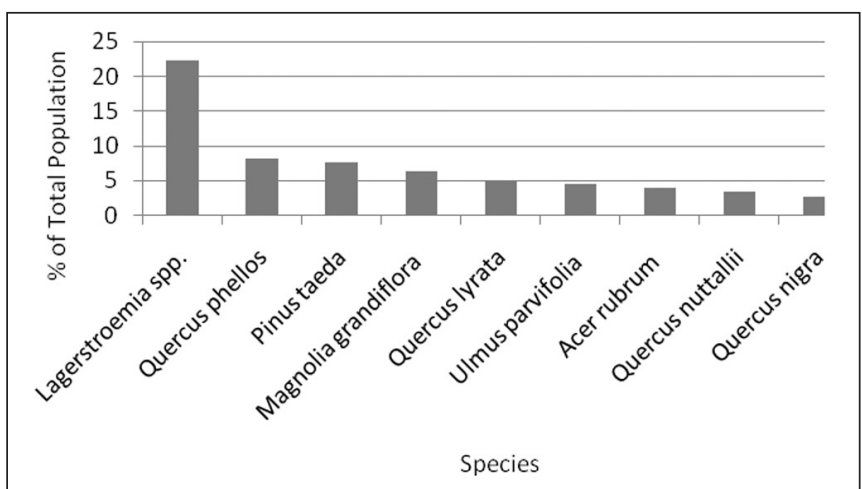

Figure 2. Percent species composition for the most common species on campus (2009-2010).

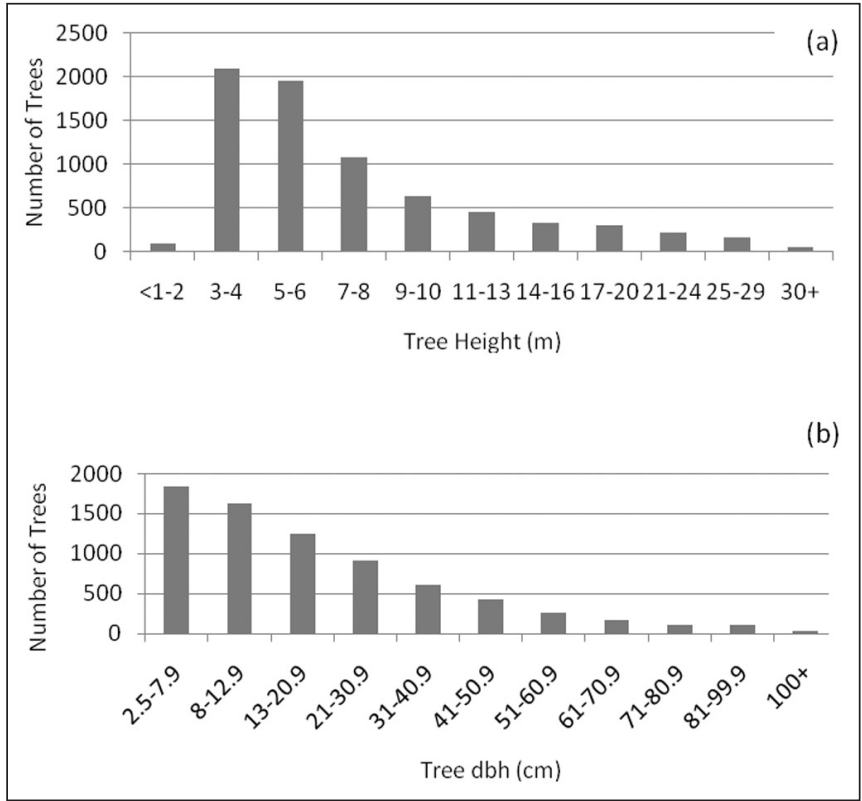

Figure 3. a) Tree height distribution and b) tree diameter distribution for the campus (2009-2010).

Table 1. Tree characteristic totals for managed areas of the Auburn University campus using i-Tree Eco inventory procedures.

Number of trees on campus

Number of species on campus

Average DBH $(\mathrm{cm})$

Average tree height (m)

Average tree crown width $(\mathrm{m})$

Basal area $\left(\mathrm{m}^{2} / \mathrm{ha}\right)$

Estimated canopy cover $(\%)^{2}$ 7,345 139

16.4

16.4
8.5

6.7

2.24

16

Estimated compensatory value (USD $\$)^{y}$

$10,757,000$

${ }^{z}$ Estimated canopy cover was calculated by using the total canopy-projected ground area calculated by the model and dividing it by the total area inventoried.

${ }^{y}$ Estimated compensatory value calculated by i-Tree Eco based on the Council of Tree and Landscape Appraisers method (i-Tree 2010d). 
Table 2. Tree characteristic totals for the most common species on campus. Parenthetical range represents the individual range for each species.

\begin{tabular}{llll}
\hline Tree species & $\begin{array}{l}\text { No. of } \\
\text { trees }\end{array}$ & Avg. DBH $(\mathrm{cm})$ & Avg. height $(\mathrm{m})$ \\
\hline Lagerstroemia spp. & 1,639 & $12.1(2.8-60.2)^{\mathrm{z}}$ & $5.0(1.8-13.7)$ \\
Quercus phellos & 596 & $12.6(5.1-142.5)$ & $6.5(3.4-20.4)$ \\
width $(\mathrm{m})$
\end{tabular}

Table 3. Contingency table for all trees on the Auburn University campus. This table contains dieback ratings and the corresponding overall tree condition rating.

\begin{tabular}{|c|c|c|c|c|c|c|c|c|}
\hline \multicolumn{9}{|c|}{ Overall Condition } \\
\hline & & $\mathrm{E}$ & G & $\mathrm{F}$ & $\mathrm{P}$ & VP & $\mathrm{D} / \mathrm{D}$ & Total \\
\hline \multirow{6}{*}{ Dieback } & $E^{z}$ & 9 & 4,113 & 1,387 & 292 & 71 & 1 & 5,873 \\
\hline & $\mathrm{G}$ & 0 & 319 & 480 & 147 & 43 & 1 & 990 \\
\hline & $\mathrm{F}$ & 0 & 13 & 130 & 115 & 68 & 2 & 328 \\
\hline & $\mathrm{P}$ & 0 & 0 & 17 & 19 & 22 & 11 & 69 \\
\hline & $\mathrm{C}$ & 0 & 0 & 2 & 13 & 4 & 10 & 29 \\
\hline & $\mathrm{D} / \mathrm{D}$ & 0 & 0 & 0 & 47 & 5 & 4 & 56 \\
\hline
\end{tabular}

${ }^{\mathrm{z}} \mathrm{E}=$ Excellent, $\mathrm{G}=$ Good, $\mathrm{F}=$ Fair, $\mathrm{P}=$ Poor, $\mathrm{C}=$ Critical, $\mathrm{VP}=$ Very Poor, $\mathrm{D} / \mathrm{D}=$ Dying/Dead

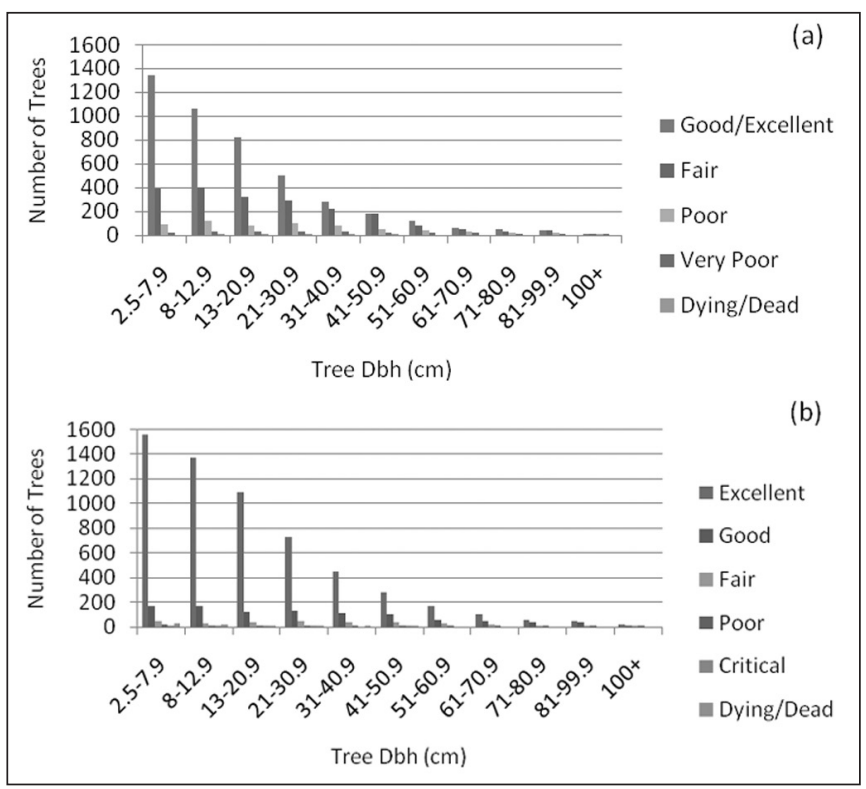

Figure 4. Tree condition by diameter class using a) overall condition class and b) percent dieback for the entire population.

In terms of species composition, all three study sites were similar in that they all contained loblolly pine (Pinus taeda), red maple (Acer rubrum), and water oak (Quercus nigra) among their top ten most common species (Escobedo et al. 2009b; Huyler et al. 2010). The university campus and the cities of Auburn and Gainesville were also similar in that the majority of the trees had a DBH $\leq 15 \mathrm{~cm}$ (Escobedo et al. 2009b; Huyler et al. 2010). Auburn University differed from Auburn and Gainesville in tree density (no/ha); where the campus had 31 trees/ha, Auburn had 985 trees/ha (Huyler et al. 2010), and Gainesville had 348 trees/ ha (Escobedo et al. 2009b). The campus also differed from the other study sites in canopy cover: the campus at $16 \%$, Auburn at 49\% (Huyler et al. 2010), and Gainesville at 51\% (Escobedo et al. 2009a). The major differences in tree cover were due to the current study only encompassing the managed areas of campus, whereas the other studies included vacant (unincorporated forest lands and vacant lots), residential, and industrial lands where basal area and density are generally much higher. It is hoped that in the future, data collected from $100 \%$ inventories using the $\mathrm{i}$ Tree Eco protocol can be used to improve plot efficiency by improving the precision of the sampling technique for collecting information on the urban forest ecosystem structure and function.

The evaluation of dieback was important because the model assigns tree condition according to the dieback rating. As i-Tree Eco was designed to assess ecosystem services that are often related to leaf functions, it focuses its condition rating on crown condition. Dieback is an important factor when evaluating tree condition (indicator of crown integrity), but cannot alone be the determining factor, considering it is only one determinate of tree health. Managers who want to really understand and manage their urban forests, and especially tree condition, must examine the entire tree. The overall condition rating developed for this project included dieback as a functional rating but also took into consideration the structural condition of the tree-the key difference between the two ratings. It was determined that using dieback as a surrogate for tree condition is not a sufficient indicator of overall tree condition. However, the results are based on comparisons between dieback and the overall tree condition rating developed for this project to provide a simple and quick assessment of tree condition; and comparisons using other condition ratings may yield different results (CTLA 2000; CITYgreen 2010; ISA 2010). The authors' current approach combined both crown and structural characteristics into one rating; however, providing individual ratings for crown and structure may provide a 
clearer picture of overall tree condition. In general, the overall condition rating resulted in a lower condition rating; however, there was a small incidence of cases (1\% of the entire population) where the overall condition rating resulted in a higher condition rating than percent dieback, which can be attributed to the observational nature of the study and the subjectivity of the crews. In the end, both the crown and structural condition of the tree need to be considered together. The study authors recommend more research be conducted on the evaluation of tree condition, either by developing a new rating system or using other established tree condition ratings (CITYgreen 2010; CTLA 2000; ISA 2010) that may yield more accurate assessments.

\section{CONCLUSION}

i-Tree Eco has the potential to become the urban tree inventory standard, presenting a valuable management tool as well as vital and accurate environmental information. This research determined that this protocol is efficient and effective for a $100 \%$ inventory of a small area. These results provide valuable information land managers can use to help manage and maintain the evolving urban forest on the Auburn University core campus. However, for i-Tree Eco to reach its full potential, further studies and inventories are needed in other locales and areas of the United States. More research dealing with the evaluation of dieback as a surrogate for tree condition is just one aspect that requires further study. With more research, i-Tree Eco can be validated for all regions of the country.

Acknowledgments. We would like to thank Dudley Hartel and Eric Kuehler of the USDA Forest Service-Urban Forestry South office for their assistance and guidance during the duration of this project. We would also like to thank Jonathon Bartlett, Mark Caldwell, Andrew Parker, Elliot Glass, Ann Huyler, and Efrem Robbins for their assistance with data collection; James Ransom and Daniel Mullenix for their technical assistance; Dr. Greg Somers for statistical guidance; and the Superintendent of Landscape Services, Charlie Crawford, for his assistance throughout the project. This project was funded in part by Auburn University and the USDA Forest Service Co-op Agreement FS-SRS-09-CA-11330150-053.

\section{LITERATURE CITED}

CTLA. 2000. Council of Tree \& Landscape Appraisers. Guide for Plant Appraisal (8thEdition). International Society of Arboriculture, Champaign, IL.

CITYgreen. 2010. American Forests: CITYgreen Environmental Education: Tree Inventory Worksheet. <http://www.americanforests.org/ downloads/citygreen/Tree\%20Inventory\%20Collction\%20She et.pdf>

Dwyer, J.F., E.G. McPherson, H.W. Schroeder, and R.A. Rowntree. 1992. Assessing the Benefits and Costs of the Urban Forest. Journal of Arboriculture 18:227-234.

Dwyer, J.F., H.W. Schroeder, and P.H. Gobster. 1991. The Significance of Urban Trees and Forests: Toward a Deeper Understanding of Values. Journal of Arboriculture 17:276-284.

Escobedo, F., J.A. Seitz, and W. Zipper. 2009a. Gainesville's Urban Forest Canopy Cover. FOR 215. School of Forest Resources and Conservation, Florida Cooperative Extension Service, Institute of Food and Agricultural Sciences, University of Florida. <http://edis.ifas.ufl. edu/FR215>
Escobedo, F., J.A. Seitz, and W. Zipper. 2009b. Gainesville's Urban Forest Structure and Composition. FOR 214. School of Forest Resources and Conservation, Florida Cooperative Extension Service, Institute of Food and Agricultural Sciences, University of Florida. <http://edis. ifas.ufl.edu/FR214>

Hauer, R.J., R.W. Miller, and D.M. Ouimet. 1994. Street Tree Decline and Construction Damage. Journal of Arboriculture 20:94-97.

Huyler, A., A.H. Chappelka, and E.F. Loewenstein. 2010. UFORE Model Analysis of the Structure and Function of the Urban Forest in Auburn, Alabama. pp. 18-23. In: Emerging Issues Along Urban-Rural Interfaces III: Linking Science and Society Conference Proceedings, Atlanta, GA. April 11-14, 2010.

ISA. 2010. International Society of Arboriculture History. <http://www. isa.arbor.com/about/History/1950.aspx>

i-Tree. 2010a. i-Tree: Tools for assessing and managing community forests. <http://www.itreetools.org >

i-Tree. 2010b. Frequently Asked Questions about the UFORE model. $<$ http://www.itreetools.org/eco/resources/UFORE\%20Model\%20 FAQs.pdf>

i-Tree. 2010c. i-Tree Software Suite v3.1 User's Manual. <http://www. itreetools.org/resources/manuals/iTree\%20Eco\%20Users\%20Manual.pdf>

i-Tree. 2010d. UFORE Methods. <http://www.itreetools.org/eco/resources/UFORE\%20Model\%20FAQs.pdf>

Matheny, N., and J. Clark. 2009. Tree Risk Assessment: What We Know (and What We Don't Know). Arborist News 18:28-33.

McPherson, E.G., D. Nowak, G. Heisler, S. Grimmond, C. Souch, R. Grant, and R. Rowntree. 1997. Quantifying Urban Forest Structure, Function, and Value: The Chicago Urban Forest Climate Project. Urban Ecosystems 1:49-61.

Nowak, D.J., and D.E. Crane. 1998. The Urban Forest Effects (UFORE) Model: Quantifying Urban Forest Structure and Functions. Integrated Tools Proceedings. pp. 714-720.

Nowak, D.J., M.H. Noble, S.M. Sisinni, and J.F. Dwyer. 2001. People \& Trees: Assessing the US Urban Forest Resource. Journal of Forestry 99:37-42.

Nowak, D.J., D.E. Crane, and J.F. Dwyer. 2002. Compensatory Value of Urban Trees in the United States. Journal of Arboriculture 28: 194-199.

Nowak, D.J., D.E. Crane, J.C. Stevens, R.E. Hoehn, J.T. Walton, and J. Bond. 2008a. A Ground-Based Method of Assessing Urban Forest Structure and Ecosystem Services. Arboriculture \& Urban Forestry 34:347-358.

Nowak, D.J., J.T. Walton, J.C. Stevens, D.E. Crane, and R.E. Hoehn. 2008b. Effect of Plot and Sample Size on Timing and Precision of Urban Forest Assessments. Arboriculture \& Urban Forestry 34: 386-390.

Pandit, R., and D.N. Laband. 2010. A Hedonic Analysis of the Impact of Tree Shade on Summertime Residential Energy Consumption. Arboriculture \& Urban Forestry 36:73-80.

Webster, B.L. 1978. Guide to Judging the Condition of a Shade Tree. Journal of Arboriculture 4:247-249.

Welch, J.M. 1994. Street and Park Trees of Boston: A Comparison of Urban Forest Structure. Landscape and Urban Planning 29:131-143. 
Nicholas A. Martin (corresponding author)

School of Forestry and Wildlife Sciences

Auburn University

Auburn, AL 36849, U.S.

nam0005@tigermail.auburn.edu

Arthur H. Chappelka

Professor

School of Forestry and Wildlife Sciences

Auburn University

Auburn, AL 36849, U.S.

Gary J. Keever

Professor

Department of Horticulture

Auburn University

Auburn, AL 36849, U.S.

Edward F. Loewenstein

Associate Professor

School of Forestry and Wildlife Sciences

Auburn University

Auburn, AL 36849, U.S.

Résumé. Le campus de l'Université Auburn dans la ville du même nom en Alabama aux États-Unis a été employé comme site d'une étude de cas à propos de l'applicabilité de i-Tree Eco au moyen de d'un inventaire complet des arbres. L'inventaire 2009-2010 de la zone sous gestion du campus couvre un territoire de 238 ha. L'information recueillie de chacun des arbres incluait le DHP, la hauteur de l'arbre, la largeur de couronne, le pourcentage de mortalité et le pourcentage de condition de santé. L'inventaire complet comportait 7345 arbres dont le Lagerstroemia spp. (lilas des Indes), le Quercus phellos (chêne-saule) et le Pinus taeda (pin à encens) étaient les espèces les plus nombreuses sur le campus. Le DHP moyen et la hauteur totale moyenne de tous les arbres étaient de $16,4 \mathrm{~cm}$ et $8,5 \mathrm{~m}$ respectivement avec un pourcentage de couverture des cimes d'approximativement $16 \%$. Deux cotes de condition ont été attribuées pour chacun des arbres et les résultats indiquaient que le pourcentage de dépérissement seul n'est pas une mesure suffisante d'évaluation de la condition de l'arbre. Dans cette étude de cas, on a observé que les procédures de $i$-Tree Eco constituaient un outil efficient et effectif et qu'elles fournissaient des informations précieuses en regard de la structure et de la fonction de la forêt urbaine de l'Université Auburn.

Zusammenfassung. Der Campus der Auburn Universität in Alabama, USA, wurde als Standort für eine Fallstudie zur Anwendbarkeit von i-Tree Eco ausgewählt, indem ein $100 \%$ iges Baumkataster verwendet wurde. Die Bauminventur von 2009-2010 auf den bewirtschafteten Flächen des Campus erstreckte sich über 238 ha. Die erhobenen Daten von jedem Baum schlossen Daten zum Brusthöhendurchmesser, der Baumhöhe, Kronenbreite, dem Totholzanteil in Prozent und eine Vitalitätsbeurteilung ein. Das komplette Kataster umfasst 7.345 Bäume mit Lagerstroemia spp., Ouercus phellos, und Pinus taeda als die häufigsten Bäume auf dem Campus. Der durchschnittliche BHD und Baumhöhe betrugen $16,4 \mathrm{~cm}$ und $8,5 \mathrm{~m}$ mit einem Kronendach von ca. $16 \%$. Zwei Vitalitätsbeurteilungen wurden für jeden Baum erhoben und die Ergebnisse zeigen, dass der Totholzanteil allein nicht ausreichend ist, um die Baumvitalität zu beurteilen. In dieser Fallstudie waren die i-Tree Eco Anweisungen ein effektives und nützliches Werkzeug, welches wertvolle Informationen bezüglich der Forststrukturen an der Auburn-Universität lieferte.
Resumen. El campus de la Universidad de Auburn en Alabama, U.S. fue usado como el sitio para un caso de estudio sobre la aplicabilidad de i-Tree Eco usando un inventario de árboles al 100\%. El inventario del 2009-2010 de las áreas manejadas del campus fue de 238 ha. La información colectada de cada árbol incluyó diámetro a la altura del pecho (DBH), altura del árbol, diámetro de la copa, porciento de muerte regresiva y condición del árbol. El inventario complete incluyó 7,345 árboles con Lagerstroemia spp. (crapemyrtle), Quercus phellos (willow oak) y Pinus taeda (loblolly pine), las especies más numerosas del campus. El DBH promedio y la altura total de todos los árboles fueron $16.4 \mathrm{~cm}$ y $8.5 \mathrm{~m}$, respectivamente, con una cobertura de copa de aproximadamente $16 \%$. Se registraron dos condiciones para cada árbol y los resultados indicaron que el porciento de muerte regresiva, solamente, no es suficiente medida para evaluar la condición del árbol. En este caso de estudio, los procedimientos i-Tree Eco son herramientas efectivas y eficientes, y proporcionan información valiosa de la estructura y función del bosque urbano en la Universidad de Auburn. 